\title{
1 \\ Reframing the debate on informal mining
}

\author{
Kuntala Lahiri-Dutt
}

It is common to see slums comprising makeshift housing, innumerable squatters, pavement-dwellers and street vendors occupying space in urban centres of Global South countries. They contain people who have migrated from rural areas in search of better living, people who carry out most of their trade in cash, or work in small workshops that manufacture components for larger industrial units. Together, these countless (and often uncounted) people, businesses, workshops and their services and produce comprise a significant part of their country's economy. They add value to the services and goods that make up most of the economy of the countries that comprise 'most of the world' (Chatterjee 2004: 59). However, these people and their economic contributions remain unknown or poorly known, loosely governed and mostly unrecorded, at times illegitimate, and often at the mercy of the state's law enforcement. Very large numbers of people constitute this economy and make a living within it while negotiating with the state and its various arms, and they remain unconsidered by the discussions in the formal parts of the economy.

Millions of poor all over the mineral tracts of Global South countries labour in a range of mineral extractive practices; some operations are small-scale, some are licensed, others evade tax payments and some have been traditionally carried out for generations in contrast to more recent establishments. Practices occur across the spectrum of mining, from the 
most artisanal and individual opportunistic enterprises to licensed smallscale firms that hire labourers on contract. Final products often reach nonlocal or even foreign markets. These mineral practices and those involved make up the subject matter of this book. These multitudes are from diverse origins, but ones located between the plough and the pick, sometimes shifting between both. Their livelihood choices and the context within which they take them up are still poorly understood, the conceptual problems they create by engagement with global commodity markets are not yet adequately debated, and the serious consequences of their labour for their own well-being and for the local environment of the areas where they operate pose an urgent problem for scholarly articulation. Miners use mercury for gold extraction, care little for rehabilitation of denuded, deforested and disturbed land, and have been at times marginalised and ostracised as reckless environmental and social criminals. Neither these people, nor their practices, have been at the forefront of debates on resource extraction, nor have they been interrogated in light of recent theoretical advancements in understanding the political economy of livelihood diversification and transformations of rural society. These informal extractive practices are described as artisanal and small-scale mining (ASM), implying that it is a 'sector' or smaller part of the resource extractive economy, and a problematic one. This definition, with clear indication to its sectoral belonging, leaves unanswered questions about its relationship with rural transformation, with globalisation and development processes, with the advent of large-scale extractive operations and extractivist economic policies followed by states, and with migration and labour studies intensely scrutinised through Marxist analyses.

One aspect of the problem centres on the question of developing a deeper understanding of a fluid, marginal and extremely poor people, and their livelihood changes under diverse pressures. This book proposes resolution through deep engagement with the problem holistically and through a multidisciplinary approach.

The term 'informal mining' in the book's title adds some clarity by informing readers that the type of mining dealt with is part of the heavily populated informal economy, in which 'most of the people' in mining today are concentrated, and which is primarily found in countries that Chatterjee (2004) describes as 'most of the world'. Such mining practices, even when licensed or legal but on a smaller scale, are characterised by informality in labour and production structures, and the rules and norms that determine practices. Several contributors to this book have 
used the more widely accepted global acronym 'ASM', and I reiterate that no difference is implied by my preferred use of the term 'informal mining'. Some ASM scholars interpret 'informality' to mean 'illegal' mining activities (for example, Verbrugge 2015) or extra-legal, following De Soto's argument ${ }^{1}$ (Siegel and Veiga 2009); however, a wider and more complex understanding of the reality of informality is possible. The term 'artisanal' conveys labour intensiveness, low technology and low capital investment common to mineral extraction processes and their essentially premodern labour organisation. ${ }^{2}$ The ennobling connotation of the term 'artisan' can be a misnomer, however. The confusion is perhaps why the International Labour Organization (ILO) consistently used a scale-based nomenclature in its various publications (Jennings 1999).

The use of 'informal' also adds a political-economic dimension to ASM literature that is increasingly nuanced and enriched by a range of explanatory approaches. The designation not only implies its contrasting binary in the formal economy to enable us to think broadly about a pluralistic, hybrid economy of resource use, ${ }^{3}$ but also draws attention to the condition of informality, ${ }^{4}$ besides aspects of labour (such as division and exploitation of labour) and aspects of production (such as simple reproduction with inexpensive and simple instruments sometimes for subsistence) within the practices and communities (Porter et al. 2011). It draws attention to the global politics over resources within which ASM has grown-neoliberal economic policies based on distinction between public and private property rights, and unitary and stable ownership based on the 'fixing of values' - to allow us to more easily understand 'the constant negotiability of value and the unmapping of space' (Roy and

\footnotetext{
1 This argument suggests that people take 'the other path' because of procedural difficulties and delays, and advises a cutting down of bureaucratic formalities associated with obtaining a licence.

2 Artisans are usually known to be endowed with a tradition of the craft they practice (Littrel and Dickson 2010). Although some peasants might have a generational history of mining as their primary occupation, as in the case of the Banjara tribe in South Kalimantan, Indonesia, or some communities amongst the Bheels in Central India, today's peasant miners are, in most cases, first-generation miners moving away from agriculture.

3 More details of this way of thinking about the economy as a whole are found in various works of Hart (2010), Gibson-Graham (2006) and Amin (2009), who emphasise that all human action always has some measure of informality.

4 The idea of informality is generally associated with modes of human settlements and is more widely debated within the urban context where settlement, housing and trade operate outside of legal structures but in full vision, cohabiting and sharing the space with more formal structures. Porter et al. (2011) argue that these are the 'other' of the way spatial planning envisions ordered social spaces, and hence are often presented as a law enforcement or policy problem. However, the basic questions are related to property rights — the rights to say who can do what and where—and issues around sustainability.
} 
Al Sayyad 2004: 5). Property rights characteristics can also be seen in a more nuanced manner. When viewed from a historical perspective, property rights can be beyond the simplistic binary of public and private, or formal and informal. Jyotishi et al. (2017) illustrate this by using the dimensions of 'excludability' and 'rivalry' to identify a matrix of institutions governing artisanal gold-mining activities in an Indian context. They show that institutions governing mining not only move from informal to the formal sphere, but can also move in a reverse direction. Again, even within formal there are shades and layers of informality when labour arrangements are considered. In an analysis of the multiple coal-mining economies in India, using detailed empirical data from the field, Lahiri-Dutt (2016) shows how the formal and informal overlap and intermingle with each other to produce 'diverse worlds' of coal mining in India. ASM has been changing the global reliable and familiar map of mineral extraction in recent decades, pushing resource and commodity frontiers (Hilson 2013) and establishing capitalist frontiers. From the analytical perspective, the political-economic framework is expansive enough to accommodate considerable social and economic diversities apparent in the experiences and practices of informal, artisanal and small-scale mining.

Drawing on the previous example, these mines and the miners are squatters on the contemporary extractive landscape and collectively comprise a radically different kind of mining commonly envisaged by the term 'mining' in the context of industrialised, large-scale extractive operations. These mines and quarries redefine what is generally seen as the extractive economy at global and national scales of interpretation. Heavily capitalised and industrialised operations that have been the dominant mode of mineral resource extraction since the industrial revolution in Europe and the New World replaced the chaotic, ruthless world that had been unleashed by rushes for mineral resources in Australia and North America. Yet, their hegemony within our thought processes make us forget that the poor-in their desperate attempt to survive and make a living in the globalised world, and suffering from dispossession and unforeseen social, economic and political pressures-are no longer completely outside the wider political-economic processes influencing resource extraction (Smith 2011). They also make us forget that mining has a long history as an ancient livelihood in many of these countries, where modern industrial production has not kept pace with the rapidity with which they were incorporated within the global economy. 
It is well documented that labourers in artisanal or informal mineral extraction practices are often the poorest and most exploited labourers, often erstwhile peasants caught in global change, and performing insecure and dangerous tasks. Although located at the margins of the mainstream mining economy, their extractive practices produce enormous amounts of mineral resources, securing a livelihood (and often a path out of poverty) for some. Although labourers in informal ASM comprise the poorest, they are also inextricably engaged with, or bound to, global commodity values and supply chains. As cheap labour, they are intimately involved in production of new extractive territories and rural economies by complicating what is meant by resource access and control. As migrant rural labour, they reshape agrarian communities and landscapes. Collectively, these miners also redefine our understanding of political economies, political ecologies and resource geographies of commodity extraction. This social and economic milieu also holds significant implications for scholarly understandings of contemporary mineral-dependent livelihoods, agrarian transitions, informality and the social meanings of destitution and poverty.

\section{Diversity and difficulties of explanation}

Almost all mineral-rich tracts in poorer countries of the Asia-Pacific, Africa and Latin America now have millions of squatters, labouring and making a living through mining in various scales and capacities, and together throwing up important conceptual and practical challenges. The great diversity of labour and production systems, organisations and mining practices blur the binary distinction between the formal and informal as they are commonly understood. In the context of a particular mineralised tract, mineral extraction ranges from smaller-scale mines and quarries worked by casual labourers in a few large enterpriseswhich run mechanised operations on reasonably sized leases and compete with many smaller firms with lower capital investment and productionto innumerable producers working their own land, most likely without licence or lease, using family labour, including children, and producing tiny amounts. Similarly, minerals extracted range from most to least valuable for many purposes: precious and semi-precious gemstones and metals such as gold; other metal ores such as copper, zinc, manganese, fluorspar and tin and coltan; industrial minerals such as limestone and marble; rare earths; and construction materials, including kaolins, feldspars, clays, sand and gravel. Together, 15 to 20 per cent of all global 
minerals and metals, including up to 80 per cent of all sapphires and up to 30 per cent of gold, is estimated to be produced in this way (Sippl and Selin 2012).

The mineral extractive practices have elements of petty commodity production, localised production, circulation and appropriation. These practices range from individual opportunistic enterprises to licensed small-scale firms hiring contract labourers. Although the labour is primarily for subsistence, extracted materials may fulfil wider market needs beyond those of a household or village community, and cannot be described simply as production for use rather than for exchange. Such mining may involve capital investment in trade and usury, and generate rent in kind rather than in money. But it also exhibits characteristics of informality such as extraction of surplus from the direct producer, political decentralisation and a fusion of economic and political power at the point of production, as well as a localised structure of power wherein landlords exercise judicial or quasi-judicial powers in relation to the dependent direct producers. Attempting to make sense of the situation, the International Council on Mining and Metals (ICMM 2010) classified these mining practices into five overlapping categories: traditional practices carried out for generations in an area that may form part of traditional livelihoods; seasonal activities that complement other livelihoods, such as agriculture or livestock rearing; permanent cohabitation in areas connected with large- or medium-scale mining, such as miners working abandoned areas, tailings dams or downstream of larger operations; shock mining resulting from unexpected events such as drought, economic collapse, commodity price fluctuations, conflict, retrenchment from mining parastatals and unexpected closure of commercial mines; and influx or opportunistic rush or rapid in-migration to an area where minerals have recently been found. However, these categories primarily look at the origin and present neither the vast diversity of extractive practices within this kind of mining, nor link them to the causes, and in a sense reflect a difficulty in approaching the thematic field.

The other difficulty is official recognition; unlike large-scale, formal, industrial mining, the definition of ASM or SSM (small-scale mining) varies widely between countries, with no universally accepted and precise definition. Only a few countries recognise ASM in state laws; for example, the People's Mining Act of Indonesia (of 1967) recognises the tradition of mining by communities in the country. In most countries, for example in India, mines are classified by size, production and labour requirement, or 
minerals commodities are classified in a way as to lend themselves to either large- or small-scale mining. ${ }^{5}$ It has remained a challenge to accurately estimate the numbers involved. For example, the figure of 35 million provided in 2005 by Communities and Small-Scale Mining (CASM) is substantially higher than the 13 million provided in 1999 by ILO. Since then, the world has experienced the main commodity boom in the late 2000s, and the implications of neoliberal economic policies on the poor have also been more fully understood. For example, in Ghana there are an estimated 1 million men and women miners operating without a licence (Tschakert 2009). The United Nations Economic Commission for Africa, in its 2011 report (UNECA 2011) on the role of minerals in the continent's development, noted the growing number of rural people in ASM. Consider also that estimates were often based on incomplete secondary data and extrapolation from limited surveys, and primarily considered extraction of high-value material commodities and precious stones such as gold and diamonds. Therefore, the material commodity under consideration partly influences estimates. The extraction of most industrial or construction commodities, such as coal or even stone, sand and gravel, are not included in this estimate. If extraction of these materials is considered, the numbers of extracting peasants would increase. Moreover, as ASM often complements or replaces other rural-based livelihoods such as farming in season, and many people can be simultaneously involved in both, a clear identification becomes difficult to offer.

Yet another challenge is the lack of standardised production regimes in ASM/SSM or informal mining, which presents an array of production and labour practices. These practices range from the most artisanal to reasonably capitalised extraction-from the sole entrepreneur trying out his luck with a pick and basket, to large-scale rushes where thousands descend upon an area to create horrendous landscapes; from community groups following traditional livelihoods to modern mechanised operations where labourers toil in bondage. The only distinctive feature is that these people make a difficult, rough and risky living, making use of what Ali (2009) described as the 'treasures of the earth'. The clientelist system resembles other 'illegal' uses of resource such as logging, which ranges from highly capitalised actors with significant funds and industrialscale operations, to mid-size entrepreneurs, down to village or family-

5 For example, in India coal is classified as a 'major mineral', implying that it can only be mined by big players, thereby illegitimising any other form of coal mining. 
based groups. For example, in south and east Kalimantan in Indonesia, informally organised operations by PETIs (penambang tanpa injin, literally translated, 'those who mine without a licence') use reasonably capital-intensive earth-moving equipment to cut coal seams and truck them to Banjarmasin port. The material is transferred onto large coal barges that supply ships outside Indonesian waters for export to China and South Korea. Yet, next to them, often occupying the same space and extracting the same resources are the 'gurandils'. These fleeting masses literally 'jump from cliff to cliff, and operate clandestinely by staying small and invisible to the state machinery of law enforcement, some selling to the local markets and others supplying the barges that carry coal from the trucks to the ships. Not far from the general region is a traditional diamond-mining area where indigenous Banjars have mined diamonds for generations. This is different from the Brazilian Amazonia where multitudes of itinerant miners-wildcat garimpeiros-clear the jungle to extract gold and other precious commodities. The Galampseys in Ghana, Barranquilas in Bolivia, and the Ninjas of Mongolia each have different contexts and characteristics. These diverse contexts are only partly the products of historical continuity in mining, and each have a distinctiveness best explained through local studies that highlight the importance of place in shaping the political-historical trajectories.

While exact numbers of these workers are unknown, we realise that the scale and extent of their presence is difficult to explain with theories developed in the context of post-industrial resource extraction and capital accumulation processes. There are stories of spectacular 'rushes' of gold or diamonds-which are often equated with those that took place in the New World-occurring throughout the mineral-rich Global South. But in analysing such a 'New Gold Rush' in Zimbabwe, Kamete (2008) found that the rush was clearly linked to the economic crash and created a situation in which 'five per cent of the official national population, are directly involved in gold panning. The numbers are increasing at a phenomenal rate' (ibid.: 40). The extent is apparent from the fact that, by the early 1990s, more than 100 metric tons of gold was produced annually, and gold-mining had become the second-most important economic activity in Amazonia (following the combined ranching/ agriculture sector) (Godfrey 1992: 460). Godfrey stated, 'At least half a million gold miners now operate in Amazonia' (ibid.). To this might be added the large number of merchants, restaurateurs, sex workers and others who service the miners. He noted, 'in certain areas, gold-mining 
has become the leading economic sector ... [and] the dynamics of goldmining ... call into question several common assumptions about the socalled agrarian frontier in Amazonia' (ibid.). Clearly, in Brazil, mining rather than agriculture has been pushing this frontier.

This evidence points to highly mobile rural communities scrambling for minerals, engaging with the market to extract values, competing with multinational mining companies or complementing them in many ways in search of minerals. The miners cannot be easily contained within concession boundaries or sedentarised as they move around and dig everywhere (referred to in Lao PDR as khut thouathip) to frustrate the governments (Lahiri-Dutt et al. 2014). The transitory nature of miners who follow the material commodities, with their undercover, surreptitious operations, make it difficult not only to explain but also to administer in the conventional way. They point to a significant change in contemporary extractive landscapes that is directly linked to stagnating rural economies.

Glimpses into a paucity of data show that this unprecedented rush has remained not only a theoretical challenge, but also is unimagined and largely unaccounted. As much as 65 per cent of Peru's gold production in 2005-06 came from non-formal sources-that is, other than from large mining companies. Gold production from informal sources in 1992 contributed an estimated 76 per cent of mineral export earnings of Tanzania (Tesha 2000). Of the nearly 600,000 carats of diamonds officially exported from Sierra Leone in 2006, as much as 84 per cent originated from peasant extraction (Government of Sierra Leone 2011). In Indonesia, in addition to gold and diamonds, coal, tin and manganese are mined informally in vast quantities, the majority reaching the international market (Lestari 2013). In Mongolia, where mining is the fastest growing segment of the national economy, former herders endure harsh winters to extract gold to reclaim their moral rights to natural resources (Lahiri-Dutt and Dondov 2016). Their numbers eclipse those employed by formal mining industries, and they produce more gold than the country's corporate mines. Approximately 20 per cent of Mongolia's labour force is thought to be engaged in mining and mineral processing without licence (UNDP 2009).

In official documentation and in social science studies, miners and mine labourers are dissociated from rural peasantry. The peasantry is conventionally regarded as a traditional occupational and demographic category comprising sedentary farming communities. The quarry labourer, 
as Bryceson (2002) observes, is typically regarded as an opportunistic rural migrant scrambling for income. Such conceptualisation enables a rethink of ASM as part of the wider global political economy. This type of mining is rewriting the meanings of commodities and materials, the meanings of places and territories, and the meanings of labour and social relations in production in a way that defies old explanations. Something unheard of before is happening: field-based scholars and experts are noting and commenting on mining, not just as involving capital and capitalist enterprise, but also as rural labour moving out and around. These rural people have been 'opening up' once remote locations to link them with global capital and commodity networks. Neither fully a labourer nor a peasant anymore, these people inhabit the margins of the mainstream mining economy; these labourers attest to the state's failure to accommodate their livelihoods within existing legislative and formal institutional frameworks (Jønsson and Bryceson 2009). Elsewhere, these miners apply techniques that involve staying small, bribing local government officers and mining in remote areas to avoid law enforcement. In yet other places, they present pathetic figures dulled by exploitationearning the lowest wages, exploited in feudal or semi-feudal production systems, unrecorded and uncared for. They are the true outcasts of modernity and modern capitalist mining expansion. Collectively, these innumerable workers, toiling in mineral-rich regions, produce enormous quantities of minerals that we are little aware of.

Of the millions who shift from rural areas to informal mining or ASMeither as independent entrepreneurs or working as groups or wage labourers - very few can rise out of poverty. These people are the new mining precariats, toiling as unstable and unregulated labourers in mines and quarries in areas that are often difficult to access and lack any services. Informal labour in the Global South highlights their diverse and multiple precarity as historically specific to the poorer countries (Breman 2013). For this reason, the lack of social insurances such as old-age pensions, health and unemployment benefits and lack of safety within the mines and quarries, assume significance. Reframing therefore involves greater attention to labour conditions within ASM, and interrogation of the state's apathy that allows such persistent conditions.

An issue often confronting those who suggest that ASM is 'poverty driven' (Jennings 1999) is the preponderance, in certain locations, of heavy mining machinery that requires sizeable amounts of capital investment. One end of informal mining is heavily mechanised with wage labour 
hired by external investors to operate the machinery. This emphasises mode of production, the integrated complex of two interdependent factors-productive forces and social relations of production. If we accept that mode of production is an articulated combination of relations and forces of production that enables capital accumulation-in turn financing the transformation of rudimentary extraction processes into mechanised operations with sophisticated work practices and revenuesharing arrangements - then it is easier to locate informal mining or ASM within petty commodity production. With increasing mechanisation and capitalisation, production quantities rapidly increase, leading to the most crucial policy question related to the environment- 'what is to be done' to address the rampant environmental degradation in open-access commons such as forests and grazing fields (Suzuki 2013).

Mining experts have offered explanations for the prevalence and contemporary growth of ASM. Geologists in remote regions have noted many people digging for minerals - sometimes valuable metals or gemstones. They explain such mining by invoking the nature of the 'reserve': the manner in which deposits of ore or minerals were laid by Mother Nature for humans to use as resource. Geologists argue that certain deposits were either too small, too 'ribbonlike', too scattered, too shallow or too remote for large-scale mechanised operations. The ease of extraction, for example of surficial placer deposits, facilitates local people to dig them up. Mining engineers noted that if some deposits are 'leftover' by large mechanical operations, they can be extracted on a small scale using low levels of technologies. In these formulations, the explanation therefore hinges on not only the properties of the materials, but also the 'scale'. Scale of the extraction is related to the 'level' of technology used: larger scale requires higher levels of capital. The hidden assumptions are not difficult to detect. The first assumption is that such mining is a scaled-down version of larger-scale mining, implying there is no essential difference between the two. This is a purely technically biased worldview that reduces human endeavours to definitions based on their size. The second assumption is that the existence of such mining is environmentally determined, implying they existed because that was the only way these minerals could be extracted. Although nature does primarily determine the availability of minerals, it is unreasonable to suggest that nature determines resource extraction. The third assumption is that small scale and low technology are correlated. This assumption has inherent problems as we now know that both are no longer correlated as they 
were; many small-scale technologies are much more widely available and accessible by those who could not previously afford it. Capital investment in small-scale mining is no longer and not always local, thereby enabling the use of a wider range of technologies-from metal detectors to find gold, through to excavators, pumps and crushers.

Environmental geologists (for example, Douglas and Lawson 2000) noted the extremely deleterious cumulative effect of small diggings spread around an area. The impact of a large number of small operations can be harmful for the overall environment: forests are cut and farming land destroyed, rivers are chocked with sediments, the water table falls, the air fills up with dust and smoke. However, some experts also offered a variation of the environmentally deterministic argument to suggest that environmental degradation, leading to severe livelihood stress, explains the growth of informal, artisanal mining. A widely used example is that of Mongolia, where several successive and extremely severe winters destroyed herding livelihoods, forcing the destitutes to take up informal mining in the early part of the new century (Fernández-Giménez et al. 2012: 836). Such environmental determinism is locally true, and it is not difficult to find examples of a degraded subsistence resource base pushing local environment-dependent communities into informal mining. This explanation, however, is only partly applicable. Most often, instead of one single cause, several factors create a situation where informal mining becomes a more attractive livelihood option for the poor.

Contrary to these observations, archaeologists and historians have presented irrefutable evidence that communities in many parts of the world have traditionally extracted minerals. Archaeologists who draw evidence from material artefacts have argued that human civilisation did not necessarily 'progress' in a linear manner from hunter-gatherers to farmers to industrial labourers. They show that sometimes mining has been the primary occupation; however, some communities have actually never been farmers as was imagined commonly in the linear explanation of advancement of human endeavour. At other times, the use of minerals or extractive activities (such as stone-cutting) was an important part of human cultures (Knapp and Pigott 1997). Social historians as well as historical archaeologists show that mining and agriculture often coexisted. For example, Phimister (1974: 445) shows that in west and south-central Africa, local inhabitants engaged in the production and trading of gold, primarily alluvial gold, for over 900 years, which is even earlier than mining from gold reefs. Reef mining started as the demand for gold 
expanded, allowing the Iron Age miners to develop more sophisticated prospecting and mining methods. ${ }^{6}$ Early alluvial gold-mining was a seasonal activity, ${ }^{7}$ undertaken 'only because of the poverty of other local resources' (Phimister 1974: 445). Although Africa was the primary source of gold for Europe for a long time, very little is known about it today. Werthmann (2007: 394) cites three reasons for this paucity of knowledge: the remarkable secrecy about the sources of gold, the many unsuccessful attempts and failures to strike new deposits, and, more importantly, the 'myth-making' around mining. Caballero (1996) reviews how goldmining continued as part of the flow of traditional livelihoods amongst the indigenous communities in Benguet province in the Philippines. In Peru, scholars (Deustua 1994; DeWind 1977) have shown that the fine details of the form of the economy varied depending on the nature of the mineral: silver mining entailed artisanal production with little technology, while copper mining demanded more capital-intensive processes of smelting and refining in plants.

In their global report on ASM, Hentschel et al. (2002: 9-10) provided an historical review of the manner in which the international development community has treated the issues. They show that the primary approach in dealing with ASM has shifted over the decades: during the 1970s, the primary focus was on definitional issues; the 1980 s reflected a preoccupation with technical issues and physical impacts; ${ }^{8}$ and, during the early 1990 s, it shifted towards integration of technical, environmental, legal, social and economic issues. Throughout the 1990s, there was particular focus on legalisation of ASM, although development planners had begun exploring the relationship between large mining corporations and ASM, focusing on more specific labour issues including gender and child labour during the mid to late 1990s. Finally, with the establishment of CASM and the Mines, Minerals and the Sustainable Development (MMSD) Project by the British non-government organisation International Institute of

6 Again, Phimister (1974: 446) thinks that reef-mining methods were owed to alluvial gold, which, in some places, was worked by shafts sunk into riverbanks.

7 Besides the need for resources to trade, geological availability and climatic and riverine factors determined alluvial gold-mining. The Angwa, Mazoe and Ruenya rivers were of importance, as were areas of Manyika (currently Mozambique), where rivers are perennial.

8 Of these, the impact of the use of mercury in gold processing — on the local environment and on populations using it—remains a concern. The Global Mercury Project, funded by the United Nations, scrutinises mercury use by artisanal gold-mining communities. It continues to focus on health and environmental impacts of mercury use by artisanal gold-mining communities. The scholarly and international policy attention on various aspects of mercury use in processing gold, while also yielding a large body of literature, was productive for social science knowledge on the extractive practices. 
Environment and Development (IIED), community issues including those related to livelihoods came to the forefront. The MMSD sponsored reports related to mining, of which the global report on ASM (Hentschel et al. 2002) remains one of the most authoritative accounts. CASM, under the auspices of British Foreign Aid and the World Bank, was to act as a global networking and coordination facility. With the mission 'to reduce poverty by improving the environmental, social and economic performance of artisanal and small-scale mining in developing countries' (ibid.: n.p.), it was also crucial in linking research with international development and policy-making. This close proximity with mainstream policy-making widened the scope of attention on ASM to the poverty and desperation of the people involved, and rescued ASM from association with sensational accounts of 'resource curse' and 'resource wars'; however, it did not really lead to full articulation of an analytical framework within which to place such mining. ${ }^{9}$ A similar shift in scholarly literature has more explicitly engaged with development: from looking at 'socio-economic impacts of ASM' (Hilson 2003) and physical impacts, to the exploration of what might be causing the rural poor to move from traditional forms of subsistence to mineral extractive practices, giving rise to a significant body of development literature (Buxton 2012, 2013). As consensus was reached that ASM is largely poverty-driven, programs and projects searched for alternative livelihoods and cooperatives for these communities, albeit with not very significant results (Levin and Turay 2008).

Anthropologists tend to explain ASM differently. Examining ASM through deep ethnographical engagement and attention on the local context, scholars (such as High 2008) contest the notion and suggest that the argument that it is spreading throughout the Global South due primarily to poverty is simplistic. High argues that, in Mongolia, such mining is linked to customary ideas about patriarchy, generosity and the obligation to share wealth. Moreover, High and Schlesinger (2010) emphasise not just the long history of mining but also the centrality of mining-particularly of gold - to Mongolian politics and economy traditionally. Rather than analysing the herders-cum-informal miners as either victims or greedy agents, High suggests that artisanal mining is linked to 'Mongolian ideas about patriarchy, generosity and specifically the obligation to share wealth'. Explaining the 'cultural logic' of informal

9 In a previous work, I have criticised the use of macroeconomic theories such as resource curse to explain ASM (see Lahiri-Dutt 2006). 
mining, she shows that many 'ninja miners' she spoke with during her 20 months in the field often 'cast themselves in opposition to mining companies, which they regard as "bad for Mongolia", "they steal our wealth"' (High 2012: 257). The moral economy of resources becomes apparent through these interpretations (also see Lahiri-Dutt 2014 for the Indian context). Ethnographic insights into social and cultural features of artisanal mining communities (such as by Walsh 2003; Grätz 2002; Nelson 2016) also allow the reader to move beyond the greed, blood and violence, and the monetisation of everyday life, which have now become associated with these mining communities. More importantly, they illuminate the importance of the specific context: deep connections to rural pasts, attitudes towards fortune-making, risk minimisation cultures and friendship ties in coping with an uncertain way of life that presents as many everyday challenges as opportunities.

The contemporary political economy of globalisation is pushing millions out of agriculture to negotiate the material world, which is the world of commodities. Rural communities are organising new systems of production and diversifying their economies and livelihoods. Sometimes, they are giving up farming altogether-a process that is described as 'de-peasantisation' ${ }^{10}$ and/or deagrarianisation. In this process, peasants leave agriculture in favour of urban jobs, or move within the agricultural wage labour circuit diversifying their livelihoods, not as a temporary measure but permanently. Scholars such as Bryceson (2002) and Bryceson and Jønsson (2010) articulate that deagrarianisation is prominent in Africa where ASM has flourished as a means of rural livelihoods diversification. Pressured from external forces, rural communities are negotiating the free market and the state to make the best of constraining and enabling opportunities, accessing knowledge, resources and vistas of rights (Bebbington 1996). Following this argument, one can argue that rural communities, ousted by extractivism of states and international agencies, are adapting to the political economy of mineral extraction, and derive some benefits from the forces that are undermining their well-being (Verbrugge 2016).

10 Araghi (2009: 138) notes that de-peasantisation is neither synonymous with proletarianisation, nor is it a completed or self-completing process leading to the death of the peasantry, and observes that peasantisation and de-peasantisation are not necessarily two mutually exclusive phenomena. 
This book examines informal, artisanal and small-scale mining, to locate it within the broader debates on rural transformation and resource politics of these countries, and the gamut of theoretical, analytical and practical challenges it presents to scholars, practitioners and policymakers. These challenges range from defining the composition of informal or artisanal and small-scale mining, theoretically explaining it, contextualising contemporary concerns over environmental integrity and labour safety standards, to governing it in a situation where no alternative livelihood plans work (Siegel and Veiga 2010). This book's contributions take up these challenges to reinterpret informal, artisanal and small-scale mining. Irrespective of historical antecedents, their collective numbers have grown to such an extent that, although scattered over (and bound to) mineralised and often remote areas, they have come under the intense scrutiny of scholars and other professionals.

\section{Structure of the book}

Contributions from multiple perspectives and disciplines reflect the diversity of ways that informal, artisanal and small-scale mining can possibly be perceived. Holistically, they represent a universe fraught with confusion and ongoing debates, and each contributes to one of three broad areas. Consequently, they are arranged into three sections. The first section deals with the historical antecedents of ASM and articulates the ways values - of commodities and of moral judgements-are constructed. The second section highlights aspects of precarious labour in this kind of mining to underline the broader political-economic perspectives. The third section focuses on aspects of conflicts and governance that pose significant difficulties in dealing with these extractive practices.

Deborah Bryceson outlines how gold rushes dramatically heighten people's expectations of the future. In societies where gold is highly valued as a source of wealth accumulation and adornment, and bears enduring economic value, the discovery of gold becomes irresistibly enticing. Contemporary gold rushes in the Global South have provided millions with a remunerative occupation, and often self-determination and local-level democracy, in ways both similar and dissimilar to the 'gold fever' that spurred large numbers to gold concentrations in the United States, Australia and Canada during the late nineteenth century. Bryceson explores what kinds of people take up shovels and picks to seek their 
livelihood or fortunes, and suggests that a historical and comparative outlook indicates the paradoxical aspects of artisanal mining as a transformative occupational frontier.

Katherine Donahue deals with an aspect of commodity production and trade: the creation of value not through labour but artificially, through middlemen and brokers. The globalised world of capitalised commodity production comprises buyers and sellers, in Tanzania and in the United States, creating a new sense of 'value' that goes beyond the use value of a commodity being its power to satisfy a want and exchange value being the quantity of other goods and services. Here, we see how economic value is created in a globalised market system through valuation principles and notions of value that create a private good for only those who own the stones. Thus, the notion of value of the commodity lies in the preparedness of someone to give up something in order to acquire what has now been constructed as a valuable commodity. Donahue shows how traditional Maasai communities participate in a global web of commoditised product-tanzanite, a gemstone that has expanded its market in recent years through publicity. She analyses this phenomenon of value creation not only for its impact on the Tanzanian economy, but also shows how the tanzanite moves through a globalised exchange system in which value is not necessarily determined by the amount of labour embodied in the gemstone.

Arnab Roy Chowdhury and Kuntala Lahiri-Dutt study gemstone mining by the Khonds, a local indigenous group or tribe. This chapter on the politically and economically volatile Kalahandi area of India shows that the recent spurt in mining has been associated with an increase in global demands and the entrance of various opportunistic outsiders who collude with the local state, caste leaders and class elites, police and bureaucracy. They present a political-economic explanation of de-peasantisation of an indigenous community to show that the Khonds have, since the opening of the Indian market of gemstones to the world, moved into the mining of gemstones. The Khonds, however, benefited little from entering the globalised world of capital — whilst out-migration has slackened, many more indigenous people are now without land and have turned into wage workers labouring in mines. In fact, the value they have created has not benefited them, as the tribes have remained just as impoverished. 
Saleem Ali argues that the time has come to consider the overall trajectory of artisanal and small-scale mining from a broader socio-ecological sustainability lens. International agencies and development donors can play significant roles to rescue it from falling into the interpretative simplistic binary of seeing ASM either as a problem of illegality or as an exemplar of entrepreneurial development. Although ASM has existed for millennia, is ingrained in many cultural traditions and has an immense livelihood potential, the ecological and health impacts remain significant. Ali suggests technical interventions to improve mineral outputs or alternative techniques for safer extraction will reduce environmental costs associated with such mining. Further, he suggests that a middle path that considers ASM as part of a hybrid livelihood strategy and a transitional opportunity for catalysing development is now needed.

Chapters in the second section of the book primarily focus on different aspects of labour processes. This section begins with the contribution of Ranabir Samaddar, who brings attention to the 'informal' condition of labour forms and its variety in terms of work, agreement, labour process and nature of the job performed. He argues that in the contemporary neoliberal economy, the extensive presence of informal labour conditions within the economy at various scales-global, national and within different sectors-signals as if there is a law ordaining the informal conditions of labour in the interest of capital in almost all spheres of economy. Based on Marxist analysis, he shows that these informal conditions can be obtained only in productive activities described broadly as 'extraction'. Moreover, labour deployed in the domain of extraction will be transient and migrant labour-in other words, multiplication of the forms of labour. These three features are interlinked, because the neoliberal economy is essentially an extractive economy, forming the backdrop to the return of primitive accumulation. The extensive emergence of labour in decentralised and informal extractive processes contributes to primitive accumulation. He proposes two sets of investigations: to investigate the wide variety of forms in which production and extraction feed into each other in the neoliberal economy, and the role transit labour plays in this dynamic; and to examine the specific nature of politics produced by the regime of extractive and transit labour.

Danellie Lynas presents the innumerable safety and health concerns of women miners. Gender is crucial in ASM communities in determining who does what, where and how. Men and women are differently involved in and differently affected by ASM practices, cultural practices and 
legislative practices. Consequently, in a traditionally patriarchal country such as Papua New Guinea, such a gendered division of labour determines economic and social power differently according to one's gender. Restricted by lack of ownership over mining land, with almost all registered mining leases, agreements and customary land held by men and transmitted patrilineally, women find themselves disadvantaged. Lynas argues that understanding how gender-specific health and safety concerns impact on the lives of the women will allow implementation of programs that directly address their needs, improve their quality of life and allow them to participate safely in extractive practices.

Lynda Lawson's chapter is about the lives of women involved in the coloured gemstone trade of East Africa. It tells the story of two groups of women: gemstone miners in rural south-west Madagascar, and women in Madagascar and East Africa who make their living further along the gemstone supply chain by adding value to gemstones through faceting, polishing, jewellery making and trade. Their life histories show how their lives have transitioned and reveal that while women in general are locked into subsistence activity, some have become skilled craftswomen and entrepreneurs.

Gernelyn Logrosa, Maureen Hassall, David Cliff and Carmel Bofinger discuss the health and safety of miners. They argue that the introduction of certain technology has the potential to alleviate or exacerbate these impacts depending on how the technology is accepted and used by miners over time. They show that using the ISO 31000:2009 standard as guidance has both notable strengths and limitations. Risk management approaches can be used to identify and assess the key factors on whether it will alleviate or exacerbate worker, family and community health and safety impacts.

In the final contribution to this section, Rachel Perks, Jocelyn Kelly, Stacie Constantian and Phuong Pham bring forth the perspectives of researcher-policy practitioner. They argue that access to finance-often seen as a perennial barrier for miners' well-being and formalisation-is the primary cause of miners suffering undercapitalisation, even when there is a legal title. The lack of financial means pushes miners to borrow, typically from middlemen buyers. The authors offer an example, based on primary research, to show how some mining networks in Rwanda are organised around off-take agreements or royalty-sharing arrangements with international trading houses, European manufacturers and local 
export houses. These alternative ways of financing are discussed against the backdrop of their application to the global industrial mining industry, to ask if such arrangements might be a step towards formalisation.

Contributions to the third section of the book are grouped around the challenges of conflicts and governance. Amalendu Jyotishi, Kuntala Lahiri-Dutt and Sashi Sivramkrishna chronicle gold-mining and informalisation processes in the Nilgiri-Wayanad region of Southern India using historical documents of the colonial period. The 1970s saw the settlement of Tamil repatriates from Sri Lanka in the region, adding a crucial dimension that helped the continuation and growth of informal gold-mining. By using a property rights framework, it explores changes in institutions and governance structures through four phases: early colonial (up to 1870 s), corporate speculation phase (from 1870 s to 1900), open-access phase (from 1900 to 1970s) and the current phase from the 1980s.

Marjo de Theije and Ton Salman present an analysis of conflicts surrounding artisanal and small-scale gold-mining in a number of countries-Bolivia, Colombia, French Guiana, Peru and Surinamelocated in the Amazon region, with a focus on notions of territoriality, marginality and access to the gold in forested and remote areas. They argue that physical and organisational distance from the centralised state plays a role in conflicts between state representatives, local communities and miners. The marginality of the territory is also created by the very act of mining activities that constitute territorial organisations and claims. They show that different politics in Amazonian countries cause conflict, but also generate opportunities for different actors. Miners cross the borders easily and without even being noticed, and differential access to the mineral-rich grounds sometimes triggers conflicts between actors.

Alexandra Urán's contribution is placed within the intensification of a neo-extractivist model of industrial and mechanised mining in Colombia during the last decade-a strategy that has excluded small-scale miners as local agents and decision makers. In areas that are literally at the margins of the official government, SSM activities occur beyond the reach of official administrative control. In the same area, the armed group has created an alternative political setting to control rural areas. The strong presence of the FARC guerrilla and other illegal armed groups in these rural areas have increased procedures for managing and administrating natural resources separately from the official legal system, and outside 
of the government's control, and they have also fabricated an extended conflict in response to the political competition for power. The chapter evaluates how the radical left in the political context may be included and recognised as a political actor to change the rules on mining and the administration of mining resources.

Sara Beavis and Andrew McWilliam focus on conflicts caused by the environmental, health and social impacts of artisanal and small-scale mining in the Indonesian archipelago where ASM is poorly governed. It highlights gold-mining in Southeast Sulawesi where there has been widespread and sustained use of elemental mercury for processing gold. This has resulted in extensive, unregulated releases of mercury into rivers that support valuable downstream land and riverine activities including irrigation, tambak fish ponds and estuarine fishing. Although the major rush since the first discoveries of alluvial gold is over, and the active mining population has declined substantially as a result of declining gold yields and greater government control over licensing and access for authorised mining companies, hydraulic mining of the riverbanks and channels continues. The legacy of mercury use has been long-lasting and deleterious for the environment. Moreover, traditional livelihoods have been affected as downstream flows in two affected river catchments still exhibit regular, extreme levels of turbidity and sediment loads-a result of intensive mining of riverbanks and beds in the upper catchments in combination with heavy seasonal monsoon rains.

The next chapter by Daniele Moretti and Nicholas Garrett brings readers back into the domain of governance. They note that much of the literature on ASM in the Asia-Pacific region suggests that national mining laws and mining governance frameworks within the region do not adequately provide for ASM. Yet, they argue, there are a few detailed and up-to-date case studies of such governance systems. Their contribution takes up the discussion of ASM governance in the Lao PDR, where ASM has long been present but has lately become an 'emerging issue', drawing increasing attention from government and international donors to show how national legal frameworks translate into, or differ from, realities on the ground. Further, it outlines ASM governance, in its current form and in light of proposed changes to ASM-specific laws, with a view to highlighting its main implications from a development perspective. 
The final chapter of this book is by Keith Barney, who outlines the elusive idea of formalisation of ASM. From regulation, ASM debates have moved onto regularisation and formalisation. Yet, the form and processes remain controversial, due to the social illegibility (the lack of data and social knowledge required for fostering state control), the resourcefulness of miners (in contesting state initiatives) and labour exploitation and presence of middlemen. Most formalisation plans are conceived as processes of integration, as means to incorporate informal activities into the sphere of state legality through some kind of group formation. However, some of these initiatives tend to be oversimplified recipes, a one-size-fits-all prescription based on standardised rules. ${ }^{11}$ Barney's contribution, drawing on evidence from three locations in India, Indonesia and Lao PDR, analyses the variations in material, social, economic, political and technological 'assemblages' of informal mining. These variations comprise what he describes as 'assemblages', producing the local contexts in all their enormous variations. He places the question of formalisation of informal mining in relation to these assemblages that comprise local socio-political struggles for rights to livelihood by local miners and resource-dependent communities, and the state-institutional governance and capital relations that reproduce vulnerability and establish conditions of informality. He recommends that public policies supporting formalisation need to better account for the connections between local processes, state institutions, the scale and use of technology, ecological externalities and the functioning of informal gold markets and commodity chains. By underlining the political nature of both miners' and local communities' livelihoods, social mobilisations and collective actions, he brings the readers back into the political economic debates.

The book ends with a postscript, which provides a rough summary of important issues emerging from the chapters and indicates new directions for possible research in future.

\section{References}

\section{Ali, S.H., 2009. Treasures of the Earth: Need, Greed and a Sustainable Future. New Haven: Yale University Press.}

11 Damonte (2016: 972) has argued that decentralisation policy based on the incorporation of local actors into the regional apparatus would foster processes of state hybridisation and gradual integration with local knowledge and skills, rather than coercion or the creation of offices that simply relocated central government authority and capacities at the sub-national or local level. 
Amin, A. (ed.), 2009. The Social Economy: International Perspectives on Economic Solidarity. Chicago: University of Chicago Press.

Araghi, F., 2009. 'The invisible hand and the visible foot: Peasants, dispossession and globalization.' In A.H. Akram-Lodhi and C. Kay (eds), Peasants and Globalization: Political Economy, Rural Transformation and the Agrarian Question. London: Routledge.

Bebbington, A., 1996. 'Movements, modernizations, and markets: Indigenous organizations and agrarian strategies in Ecuador.' In R. Peet and M. Watts (eds), Liberation Ecologies. London: Routledge.

Breman, J., 2013. Outcast Labour in Asia: Circulation and Informalization of the Workforce at the Bottom of the Economy. New Delhi: Oxford University Press.

Bryceson, D.F., 2002. 'Multiplex Livelihoods in Rural Africa: Recasting the 'Terms and Conditions of Gainful Employment.' The Journal of Modern African Studies 40(1): 1-28. doi.org/10.1017/S0022278X01003792

Bryceson, D.F. and J.B. Jønsson, 2010. 'Gold Digging Careers in Rural EastAfrica: Small-Scale Miners' LivelihoodChoices.' WorldDevelopment 38(3): 379-92. doi.org/10.1016/j.worlddev.2009.09.003

Buxton, A., 2012. 'MMSD+10, Reflecting on a Decade of Mining and Sustainable Development.' IIED Discussion Paper. London: International Institute for Environment and Development.

Buxton, A., 2013. Responding to the Challenge of Artisanal and Small-Scale Mining: How Can Knowledge Networks Help? London: International Institute for Environment and Development.

Caballero, E., 1996. Gold from the Gods: Traditional Small-Scale Miners in the Philippines. Quezon City, Manila: Giraffe Books.

Chatterjee, P., 2004. The Politics of the Governed. New York: Columbia University Press.

Damonte, G.H., 2016. "The "Blind" State: Government Quest for Formalization and Conflict with Small-scale Miners in the Peruvian Amazon.' Antipode 48(4): 956-76. doi.org/10.1111/anti.12230

Deustua, J., 1994. 'Mining, Markets, Peasants, and Power in Nineteenth Century Peru.' Latin American Research Review 29(1): 29-54. 
DeWind, A., 1977. 'Peasants Become Miners: The Evolution of Industrial Mining Systems in Peru.' Columbia University (PhD thesis).

Douglas, I. and N. Lawson, 2000. 'The Contribution of Small-Scale and Informal Mining to Disturbance of the Earth's Surface by Mineral Extraction.' Mining and Energy Research Network Research Bulletin 15: 153-61.

Fernández-Giménez, M., B. Batkhishig and B. Batbuyan, 2012. 'CrossBoundary and Cross-level Dynamics Increase Vulnerability to Severe Winter Disasters (Dzud) in Mongolia.' Global Environmental Change 22(4): 836-51. doi.org/10.1016/j.gloenvcha.2012.07.001

Gibson-Graham, J.K., 2006. A Postcapitalist Politics. Minneapolis: University of Minnesota Press.

Godfrey, B.J., 1992. 'Migration to the Gold-mining Frontier in Brazilian Amazonia.' Geographical Review 82(4): 458-69. doi. org/10.2307/215202

Government of Sierra Leone, 2011. 'An Overview of the Sierra Leone Minerals Sector.' Viewed at embassyofsierraleone.net/about-sierraleone/mining/mineral-sector-overview (site discontinued)

Grätz, T., 2002. 'Gold Mining Communities in Northern Benin as Semi-autonomous Social Fields.' Working Paper no. 36. Halle/Saale: Max Planck Institute for Social Anthropology.

Hart, K., 2010. 'Informal economy.' In K. Hart, J.L. Laville and A.D. Cattani (eds), The Human Economy. Cambridge, UK: Polity Press.

Hentschel, T., F. Hruschka and M. Priester, 2002. Global Report on Artisanal \& Small-Scale Mining. Minerals Mining and Sustainable Development, no. 70. International Institute for Environment and Development, World Business Council for Sustainable Development.

High, M., 2008. 'Wealth and Envy in the Mongolian Gold Mines.' Cambridge Anthropology 27(3): 1-18.

High, M., 2012. 'The Cultural Logics of Illegality: Living Outside the Law in the Mongolian Gold Mines.' In J.B. Dierkes (ed.), Change in Democratic Mongolia: Social Relations, Health, Mobile Pastoralism, and Mining. Leiden: E.J. Brill. doi.org/10.1163/9789004231474_013 
High, M. and J. Schlesinger, 2010. 'Rulers and Rascals: The Politics of Gold Mining in Mongolian Qing History.' Central Asian Survey 29(3): 289-304. doi.org/10.1080/02634937.2010.518008

Hilson, G.H., 2003. 'Gold Mining as Subsistence: Ghana's Small-Scale Miners Left Behind.' Cultural Survival 27(1): n.p.

Hilson, G., 2013. "'Creating” Rural Informality: The Case of Artisanal Mining in Sub-Saharan Africa.' SAIS Review of International Affairs 33(1): 51-64. doi.org/10.1353/sais.2013.0014

International Council on Mining and Metals (ICMM), 2010. Working Together-How Large-scale Miners can Engage with Artisanal and Small-scale Miners. International Council on Mining and Metals (ICMM), Communities and Small-Scale Mining (CASM) and International Finance Corporation (IFC) Oil, Gas and Mining Sustainable Community Development Fund.

Jennings, N., 1999. 'Social and Labour Issues in Small-Scale Mines.' Report for discussion at the Tripartite Meeting on Social and Labour Issues in Small-Scale Mines. Geneva: International Labour Organization.

Jønsson, J.B. and D.F. Bryceson, 2009. 'Rushing for Gold: Mobility and Small-Scale Mining in East Africa.' Development and Change 40(2): 249-79. doi.org/10.1111/j.1467-7660.2009.01514.x

Jyotishi, A., S. Sivramkrishna, K. Lahiri-Dutt, 2017. 'Gold Mining Institutions in Nilgiri-Wayanad: A Historical-Institutional Perspective.' Economic and Political Weekly 52(28).

Kamete, A.Y., 2008. 'When Livelihoods Take a Battering: Mapping the "New Gold Rush" in Zimbabwe's Angwa-Pote Basin.' Transformation: Critical Perspectives on Southern Africa 65: 36-67. doi.org/10.1353/ trn.2008.0009

Knapp, A.B. and V. Pigott, 1997. 'The Archaeology and Anthropology of Mining: Social Approaches to an Industrial Past.' Current Anthropology 38(2): 300-4. doi.org/10.1086/204613

Lahiri-Dutt, K., 2006. "May God Give Us Chaos, so That We Can Plunder": A Critique of "Resource Curse" and Conflict Theories.' Development 49(3): 14-21. doi.org/10.1057/palgrave. development. 1100268 
Lahiri-Dutt, K., 2014. 'Between Legitimacy and Illegality: Informal Coal Mining at the Limits of Justice.' In K. Lahiri-Dutt (ed.), The Coal Nation: Histories, Politics and Ecologies of Coal in India. Aldershot: Ashgate.

Lahiri-Dutt, K., 2016. 'The Diverse Worlds of Coal in India: Energising the Nation, Energising Livelihoods.' Energy Policy 99: 203-13.

Lahiri-Dutt, K., K. Alexander and C. Insouvanh, 2014. 'Informal Mining in Livelihood Diversification: Mineral Dependence and Rural Communities in Lao PDR.' South East Asia Research 22(1): 103-22. doi.org/10.5367/sear.2014.0194

Lahiri-Dutt, K. and H. Dondov, 2016. 'Informal Mining in Mongolia: Livelihood Change and Continuity in the Rangelands.' Local Environment 22(1): 126-36. doi.org/10.1080/13549839.2016.1176012

Lestari, N.I., 2013. 'Mineral Governance, Conflicts and Rights: Case Studies on the Informal Mining of Gold, Tin and Coal in Indonesia.' Bulletin of Indonesian Economic Studies 49(2): 239-40. doi.org/10.108 0/00074918.2013.809847

Levin, E. and A.B. Turay, 2008. 'Artisanal Diamond Cooperatives in Sierra Leone: Success or Failure?' Ottawa: Partnership Africa Canada. Available at www.africaportal.org/dspace/articles/artisanal-diamondcooperatives-sierra-leone-success-or-failure

Littrel, M.A. and M.A. Dickson, 2010. Artisans and Fair Trade: Crafting Development. Sterling, VA: Kumarian Press.

Nelson, H., 2016. Black, White and Gold: Gold Mining in Papua New Guinea, 1878-1930. Canberra: ANU Press.

Phimister, I.R., 1974. 'Alluvial Gold Mining and Trade in Nineteenthcentury South Central Peru.' The Journal of African History 15(3): 445-56. doi.org/10.1017/S002185370001358X

Porter, L., M. Lombard, M. Huxley, A.K. Ingin, T. Islam, J. Briggs, D. Rukmana, R. Devlin and V. Watson, 2011. 'Informality, the Commons and the Paradoxes for Planning: Concepts and Debates for Informality and Planning.' Planning Theory and Practice 12(1): 11553. doi.org/10.1080/14649357.2011.545626 
Roy, A. and N. Al Sayyad, 2004. 'Prologue/dialogue. Urban informality: crossing borders.' In A. Roy and N. Al Sayyad (eds), Urban Informality: Transnational Perspectives from the Middle East, Latin America and South Asia. Oxford: Lexington Books.

Siegel, S. and M.M. Veiga, 2009. 'Artisanal and Small-Scale Mining as an Extralegal Economy: De Soto and the Redefinition of "formalization". Resources Policy 34(1-2): 51-6. doi.org/10.1016/j. resourpol.2008.02.001

Siegel, S. and M.M. Veiga, 2010. 'The Myth of Alternative Livelihoods: Artisanal Mining, Gold and Poverty.' International Journal of Environment and Pollution 41(3): 272-88. doi.org/10.1504/ IJEP.2010.033236

Sippl, K. and H. Selin, 2012. 'Global Policy for Local Livelihoods: Phasing Out Mercury in Artisanal and Small-Scale Gold Mining.' Environment, Science and Policy for Sustainable Development 54(3): 18-29. doi.org/10.1080/00139157.2012.673452

Smith, J.H., 2011. 'Tantalus in the Digital Age: Coltan Ore, Temporal Dispossession and "Movement" in the Eastern Democratic Republic of Congo.' American Ethnologist 38(1): 17-35. doi.org/10.1111/ j.1548-1425.2010.01289.x

Suzuki, Y., 2013. 'Conflict between Mining Development and Nomadism in Mongolia.' In N. Yamamura, N. Fujita and A. Maekawa (eds), The Mongolian Ecosystem Network: Environmental Issues Under Climate and Social Changes. Tokyo: Ecological Research Monographs. doi. org/10.1007/978-4-431-54052-6_20

Tesha, A.L., 2000. 'Cooperation Between Small-Scale and Large-Scale Mining: Tanzania Experience.' Paper presented at the Growth and Diversification in Mineral Economies: Regional Workshop for Mineral Economies in Africa, Cape Town, South Africa, 7-9 November. Viewed at www.unctad.org/infocomm/diversification/cape/pdf/tesha. pdf (site discontinued)

Tschakert, P., 2009. 'Recognizing and Nurturing Artisanal Mining as a Viable Livelihood.' Resources Policy 34(1-2): 24-31. doi. org/10.1016/j.resourpol.2008.05.007 
UNDP (United Nations Development Programme), 2009. 'Mongolia Human Development Report 2007.' Unpublished report to the UNDP. Ulaanbaatar: UNDP Mongolia.

United Nations Economic Commission for Africa (UNECA), 2011. 'Minerals and Africa's Development.' The International Study Group Report on Africa's Mineral Regimes.

Verbrugge, B., 2015. 'The Economic Logic of Persistent Informality: Artisanal and Small-Scale Mining in the Southern Philippines.' Development and Change 46(5): 1023-46. doi.org/10.1111/ dech.12189

Verbrugge, B., 2016. 'Voices From Below: Artisanal and Small-Scale Mining as a Product and Catalyst of Rural Transformation.' Journal of Rural Studies 47: 108-16. doi.org/10.1016/j.jrurstud.2016.07.025

Walsh, A., 2003. "Hot Money" and Daring Consumption in a Northern Malagasy Sapphire-mining Town.' American Ethnologist 30(2): 290-305. doi.org/10.1525/ae.2003.30.2.290

Werthmann, K., 2007. 'Gold Mining and Jula Influence in Pre-colonial Southern Burkina Faso.' Journal of African History 48(3): 395-414. doi.org/10.1017/S002185370700326X 
This text is taken from Between the Plough and the Pick: Informal, artisanal and small-scale mining in the contemporary world, edited by Kuntala Lahiri-Dutt, published 2018 by ANU Press, The Australian National University, Canberra, Australia.

doi.org/10.22459/BPP.03.2018.01 